\title{
ПОЛЬЩА ТА РОСІЙСЬКО-УКРАЇНСЬКИЙ КОНФЛІКТ
}

\section{Мітрофанова Оксана Олександрівна}

кандидат політичних наук, старший науковий співробітник,

ДУ «Інститут всесвітньої історії НАН України»,

м. Київ, Украӥна

Надіслано:

10.03.2021

Рецензовано:

20.03.2021

Прийнято:

05.04 .2021

ORCID: 0000-0002-2703-4919

kyivparis@ukr.net

Метою є аналіз позиції Польщі щодо російсько-українського конфлікту, анексії Криму та врегулювання ситуації в Донбасі. Серед методів було застосовано системний для вивчення сприйняття польськими політиками окупації Донбасу та анексії Криму, компаративний аналіз позицій європейських та польських діячів стосовно гіпотетичної участі Польщі у нормандському або іншому форматі 3 урегулювання російсько-українського конфлікту. Проаналізовано офіційну позицію Польщі щодо російсько-українського конфлікту 2014-2020 рр.

Доведено, що для Польщі Україна є зоною особливих інтересів. Офіційна Варшава прагне відігравати значну роль у врегулюванні російськоукраїнського конфлікту, тому що провал України означатиме для Польщі погіршення власної безпекової ситуації. Наразі польський кордон з Україною $\epsilon$ рубежем ЄС та НАТО, тому оптимальним для Польщі було б пересунення меж цих організацій у майбутньому на Схід України, тому Польща наполегливо обстоює євроінтеграційні та євроатлантичні амбіції України.

Зроблено висновок, що у польських політиків $\epsilon$ розуміння, що перетворення конфлікту на Донбасі на заморожений означатиме наявність постійної вибухонебезпечної ситуації. Зроблено рекомендації, що чіткі сигнали офіційній Варшаві 3 боку офіційного Києва 3 приводу зацікавленості у практичному втіленні польсько-українського стратегічного партнерства були б важливими та далекоглядними. Виділено, що реалізація польської політики щодо російсько-українського конфлікту залежить від стратегій основних гравців європейського стратегічного простору. Польська політика сприймається як проамериканська французькими та німецькими можновладцями, тому офіційний Париж і Бонн уникають залучення Польщі до перемовин щодо ситуації на Донбасі. Втім, самостійно Польща не здатна

(C)Мітрофанова 0. 0., 2021 


\section{Міжнародні відносини: теоретико-практичні аспекти \\ Випуск 7 (2021) \\ ISSN (print) 2616-745X; ISSN (online) 2616-7794}

впливати на врегулювання російсько-українського конфлікту, Варшава має діяти спільно з найпотужнішими гравцями.

Ключові слова: Україна; Польща; нормандський формат; Крим; Донбас.

\section{Вступ}

У новій холодній війні Польща не тільки знаходиться на стороні Заходу, але $є$ повноправним членом НАТО, а отже, й розраховує на гіпотетичний захист усією потугою Північноатлантичного альянсу. Україна у новій холодній війні постає як незалежна держава, актор міжнародних відносин.

Спільним для участі України та Польщі у двох холодних війнах $є$ те, що під час першої вони разом протистояли країнам Заходу на чолі зі США, тоді як у новій холодній війні обидві протистоять Росії, хоча й різним чином: Польща через санкції, а Україна через військовий захист свого кордону на Сході та спробу вирішити питання анексії Криму.

Відносини України 3 Польщею визначаються як стратегічне партнерство. Офіційна Варшава послідовно підтримує євроатлантичну та євроінтеграційну політику України. Вивчення підходів польських політиків щодо анексії Криму та окупації Донбасу набуває особливої значущості за умов загострення відносин з іншими сусідами України, зокрема Угорщиною. 3 одного боку, Польща не може справляти значного впливу на врегулювання російсько-українського конфлікту, з іншого, постійна підтримка західного сусіда $є$ бажаною, особливо в контексті зміцнення польсько-українських контактів. На порядку денному зовнішньополітичного відомства України має бути постійний діалог 3 Польщею і через те, що у Польщі знаходиться 1,5 млн українців на заробітках та навчанні. Аналіз стратегії Польщі щодо України на тлі російсько-українського конфлікту становить важливе питання для дослідження у царині міжнародних відносин і дипломатії.

\section{Аналіз останніх досліджень і публікацій}

Суттєвим джерелом аналізу підходів Польщі щодо російськоукраїнського конфлікту є позиції президентів Польщі, зокрема, Л. Валенси, А. Дуди, заступника голови комісії Сейму Польщі у закордонних справах В. Ващиковського, колишнього міністра фінансів Л.Бальцеровича. Можна виділити розробки польського професора, генерала у відставці С. Кожея та польського дослідника Я. Раубо.

\section{Формулювання цілей статті}

Метою $є$ аналіз позиції Польщі щодо російсько-українського конфлікту, анексії Криму та врегулювання ситуації в Донбасі. Серед методів було 
застосовано системний для вивчення сприйняття польськими політиками окупації Донбасу та анексії Криму, компаративний аналіз позицій європейських і польських діячів стосовно гіпотетичної участі Польщі у нормандському або іншому форматі з урегулювання російсько-українського конфлікту.

Аналізуються польські позиції щодо російсько-українського конфлікту. Виокремлено французькі підходи стосовно гіпотетичної участі Польщі у нормандському форматі на основі особистих інтерв'ю автора з працівниками МЗС Франції, політичними експертами і науковцями.

\section{Виклад основного матеріалу дослідження}

Польсько-українські відносини характеризуються як стратегічне партнерство. Польські політики від початку подій на Майдані були активними. Представники європейських країн спробували сприяти врегулюванню ситуації в Україні на поч. 2014 р. шляхом перемовин між Президентом В.Януковичем та представниками опозиції. У результаті 21 лютого 2014 р. було підписано Угоду про врегулювання кризи в Україні Президентом України В.Януковичем, керівником парламентської фракції політичної партії «УДАР» В.Кличком, керівником парламентської фракції «ВО «Батьківщина» А. Яценюком, керівником парламентської фракції «ВО «Свобода» О.Тягнибоком. Від Європейського Союзу Угоду засвідчили федеральний міністр закордонних справ Федеративної Республіки Німеччина Франк-Вальтер Штайнмаєр, міністр закордонних справ Республіки Польща Радослав Сікорський та керівник Департаменту континентальної Європи Міністерства закордонних справ Французької республіки Ерік Фурньє.

$€$ думка, що наміри західних підписантів різнилися: для Франції першочерговим було якнайшвидше отримати організацію демократичних виборів за участі Ю.Тимошенко, яку належало звільнити 3 в'язниці, для Німеччини - уникнути напруги у відносинах з Росією, для Польщі посилити свій вплив в Україні. Як це не дивно, тодішня посередницька місія європейців сприймається у Франції як успішна. Однак досі залишається ряд не з'ясованих питань (хто наказав вбивати людей на Майдані і чи була втеча Януковича підготовлена Росією?) (прим. автора).

Безперечно Польща намагається бути активною у царині обговорення та пошуку методів урегулювання порушення територіальної цілісності України. Відомо, що офіційної Варшави немає серед підписантів Будапештського меморандуму, як неядерна держава Польща не надавала гарантій безпеки Україні у зв'язку з денуклеарізацією останньої, втім історичний досвід взаємин з Росією, національні інтереси та прагнення відігравати роль реального

(С)ітрофанова 0. 0., 2021 


\section{Міжнародні відносини: теоретико-практичні аспекти \\ Випуск 7 (2021) \\ ISSN (print) 2616-745X; ISSN (online) 2616-7794}

стратегічного партнера спонукають Польщу підтримати Україну в конфлікті з Росією.

Францією та Німеччиною було утворено нормандський формат. У нормандському місті Бенувіль 6 червня 2014 р. відзначалося 70-а річниця операції «Оверлорд». Лідери Німеччини, Франції, України, Росії згадували про Другий фронт Другої світової війни. Перемовини та зустрічі у чотиристоронньому форматі Україна - Німеччина - Франція - Росія започатковано для врегулювання російсько-українського збройного конфлікту на Сході України.

Незабаром президент Польщі Анджей Дуда оприлюднив пропозицію Президенту України Петру Порошенку створити новий формат перемовин щодо врегулювання ситуації в Донецькій та Луганській областях за участю Польщі та інших країн-сусідів України, зокрема Польщі (Prezydent Andrzej Duda: do rozmów o Ukrainie mogliby dołączyć jej sąsiedzi i USA, 2015).

Лешек Бальцерович, польський економіст, колишній міністр фінансів зауважував, що Україна має отримувати значну увагу від Заходу, через наявність кордонів із Росією і виклик, який спричинив для ЄС та НАТО президент Росії Путін захопивши Крим та неофіційно втрутившись у Східну Україну (Balczerovich: Zapad dolzhen udelyat`Ukraine...., 2015).

Показово, що для колишнього президента Польщі Леха Валенси європейці не виявили належну активність щодо врегулювання російськоукраїнського конфлікту, як на нього Європі бракує організації, без якої буде важко досягти успіху, та й взагалі нагадував, що свого часу він передбачав можливість запобігання майбутніх конфліктів на терені України, а саме: через вступ Польщі до ЄС та НАТО разом із Україною та Білоруссю. До того ж, він вважав, що це було можливим, але не відбулося через те, що він не мав підтримки. Цілком ймовірно, що концепція Л. Валенси відповідає дійсності та висвітлює, що країнам-засновникам ЄС бракує стратегічного бачення розвитку майбутнього Європи. Можливо, ЄС, який, насамперед, виник як Європейська спільнота з вугілля та сталі, досягаючи суттєвих успіхів в економіці, трохи занедбав свою політичну складову або надав перевагу економічній сфері, відсуваючи на другорядний план потреби спільної зовнішньої політики та безпеки. Показово, що цей процес цілком очевидний польським політикам, і ця незбалансованість в обранні пріоритету серед безпеки та економіки спонукала відомого польського економіста Л.Бальцеровича спробувати розтлумачити це європейцям (Valensa: Konfliktovi na Skhodi Ukrainy..., 2015).

На думку президента Польщі А. Дуди, Євросоюз маргіналізує агресію Росії щодо України. Дуда чітко дав зрозуміти, що конфлікт в Україні повинен 
закінчитися довготривалим миром, а не заморожуванням. А довготривалий мир означає повернення до кордонів, визнаних світовим співтовариством.

Він вважає, що для майбутнього Європи потрібна єдність та партнерство країн-членів $€ C$, але «егоїзм» окремих держав може перекреслити це майбутнє (Prezydent Polshchi..., 2015).

Позицію президента підтримав заступник голови комісії Сейму Польщі у закордонних справах В. Ващиковський. На престижному 25-му Економічному форумі у Криниці-Здруй у Польщі 8 вересня 2015 р. він оголосив, що про «нормандський формат» варто забути, тому що згідно його позиції «Це - концерн наддержав, який відповідає російським мріям, щоб Європою керували кілька країн. Тут треба подумати про новий формат - Женевський чи будь-який інший, де будуть країни, які межують з Росією й Україною. Йдеться про Польщу, Румунію, можливо, Туреччину, якщо вона матиме бажання долучитися, і Штати, які ми сприймаємо як партнера Європи». Ващиковський висловився, що $€$ незначними шанси, що Україна відновить контроль над своїм кордоном, що вибори на Донбасі будуть демократичними, тому у форматі мають бути присутніми інші міжнародні організації , а не тільки «безпорадна» ОБСЄ (Pro «normanskyi format» slid zabuty..., 2015).

Водночас, французькі дипломатичні кола підкреслюють, що «нормандський формат» $\epsilon$ французькою ініціативою. Представникам чотирьох країн працювати дуже важко, тому гіпотетичне розширення кола учасників «нормандського» формату малоймовірне. Це ще більше знизить його дієвість та ускладнить роботу. До того ж, на думку французьких дипломатів, проблемою в його функціонуванні $\epsilon$ позиція Росії, а не відсутність деяких держав, наприклад Польщі (прим. автора).

Між тим, треба мати на увазі, що засновники нормандського формату вже давно взаємодіють з Польщею у рамках Веймарського трикутника, консультації у рамках якого провадяться з $1991 \mathrm{p}$., де під час зустрічей обговорюються й питання, пов'язані з безпекою. Збіг інтересів Франції і Польщі свого часу позитивно позначився на малосторонній інституалізації в рамках Веймарського трикутника. Прикметно, що політичний діалог у рамках означеної організації пролонгувався в інтенсифікації співпраці саме у військовій сфері.

Ідея цієї співпраці виникла на зустрічі міністрів закордонних справ К. Скубішевського, Р. Дюма і Г.-Д. Геншера в 1991 р. у Веймарі.

До французько-німецького співробітництва органічно долучився новий актор - Польща. Прикметно, що декларативне політичне співробітництво

(С)Мтрофанова 0. 0., 2021 


\section{Міжнародні відносини: теоретико-практичні аспекти \\ Випуск 7 (2021) \\ ISSN (print) 2616-745X; ISSN (online) 2616-7794}

привело до реальних зрушень у практичній площині: було розпочато практичну військову співпрацю за сприяння міністрів оборони.

Отже, незважаючи майже на тридцятирічну діяльність Веймарського трикутника, цей формат не було застосовано замість нормандського.

Хоча, французькі закиди полякам стосовно їхнього тяжіння до НАTO $€$ досить показовими. Одначе пронатовська політика Варшави не $\epsilon$ чимось несподіваним, позаяк об'єктивно найбільш активним та дійовим інститутом європейської безпеки на сучасному етапі $\epsilon$ НАТО, до того ж, серед інших структур європейської безпеки Північноатлантичний альянс вирізняється своєю значною військовою та фінансовою могутністю.

Французько-німецьке співробітництво постійно характеризується як важливий чинник функціонування ЄС та сприймається як дещо належне. Утім, якщо польсько-українське стратегічне партнерство є реальним, а не лише декларативним, то цілком логічно, що Україна має очікувати більшої підтримки від Польщі, ніж від інших сусідів. Отже, так само як французько-німецька співпраця $€$ загальноприйнятою реалією й у двосторонньому партнерстві, й у функціонуванні на рівні ЄС, так і польсько-українське співробітництво може стати звичайним фактом європейської політики, якщо обидві країни впораються належно позиціонувати своє партнерство за умов, коли одна з них $\epsilon$ членом ЄС та НАТО, а інша - ні, та подолають протиріччя, пов'язані 3 історичним минулим. Хоча наразі ця парадигма не знайшла свого практичного втілення у залученні Польщі разом з Францією та Німеччиною у перемовини з урегулювання російсько-українського конфлікту.

На сучасному етапі для наукового дискурсу притаманні спроби з'ясувати доцільність застосування терміна «нова холодна війна» до відносин Росії з країнами Заходу та констатується значна популярність терміна «гібридна війна» для описання агресії Росії щодо України. Своєрідним трендом у сучасній суспільній науці стали численні роботи з дослідження гібридної війни. Утім, нова холодна війна $€$ дискусійною, підходи науковців $\epsilon$ різноманітними, отже, принагідно, можна спробувати виокремити деякі аргументи прихильників і супротивників застосування терміна «нова холодна війна» до подій, які відбуваються через російсько-український конфлікт.

Польський професор, генерал у відставці С. Кожей $\epsilon$ прихильником терміна «гібридної холодної війни», а також «нової холодної війни» та «другої холодної війни» через те, що вони адекватно передають сутність відносин між Росією та Заходом, а особливо між Росією та НАТО. Фахівець виокремлює наявність класичних проявів першої холодної війни у другій: політична 
конфронтація без перетину межі, за якою починається гаряча війна та безпосередня збройна перемога. Формами конфронтації, які були присутніми і у першій холодній війні, $є$ пропагандистські кампанії, економічні санкції, шпигунство, демонстраційні військові маневри, дорогі програми 3 озброєння, які спричиняють розкручування гонки озброєння. Новими елементами, згідно С. Кожея, $є$ відсутність міжблокового характеру, менше ідеологічного протистояння, поява змагання у кіберпросторі, обмежені, приховані конфлікти. Професор виокремлює як основоположну характеристику нової холодної війни гібридність, тобто радикальну різноманітність засобів і методів протистояння (Koziej, 2018).

Утім, співвітчизник генерала польський фахівець Я. Раубо вважає, що термін «нова холодна війна» стосується хронологічних рамок, а не певної інноваційності змагань, мети чи засобів. Отже, як на нього, все частіше спостерігається переплетіння криз, подібних отруєнню С. Скрипаля, 3 періодами усталених відносин та взаємною толерантністю до підвищеної активної діяльності спеціальних служб (Raubo, 2018).

\section{Висновки}

Таким чином, для Польщі Україна є зоною особливих інтересів. Офіційна Варшава прагне відігравати значну роль у врегулюванні російськоукраїнського конфлікту, тому що провал України означатиме для Польщі погіршення власної безпекової ситуації. Наразі польський кордон з Україною $\epsilon$ межею ЄC та НАТО, тому оптимальним для Польщі було б пересунення рубежів цих організацій у майбутньому на Схід України, тому Польща наполегливо обстоює євроінтеграційні та євроатлантичні амбіції України. У польських політиків $є$ розуміння, що перетворення на заморожений конфлікт на Донбасі означатиме наявність постійної вибухонебезпечної ситуації. Утім, найпотужніші держави ЄС: Німеччина та Франція - проти залучення Польщі у нормандський формат, попри спільну діяльність у Веймарському трикутнику.

Показово, що реалізація польської політики щодо російськоукраїнського конфлікту залежить від стратегій основних гравців європейського стратегічного простору. Польська політика сприймається як проамериканська французькими та німецькими можновладцями, тому офіційний Париж та Бонн уникають залучення Польщі до перемовин щодо ситуації на Донбасі. Втім, самостійно Польща не є здатною впливати на врегулювання російсько-українського конфлікту, Варшава має діяти спільно 3 найпотужнішими гравцями. Таким чином, загальне сприйняття польської

(Мітрофанова 0. 0., 2021 


\section{Міжнародні відносини: теоретико-практичні аспекти \\ Випуск 7 (2021) \\ ISSN (print) 2616-745X; ISSN (online) 2616-7794}

зовнішньої політики визначатиме стратегію провідних країн стосовно залучення Польщі до перемовин з питань російсько-українського конфлікту.

Польща не прагне брати участь у військовому захисті державних кордонів України. Хоча, Варшава не готова допомагати ані солдатами, ані постачанням летальної зброї, втім вона надає гуманітарну допомогу та інструкторів.

За умов активізації участі США у врегулюванні російсько-українського конфлікту могла б посилитися й роль Польщі. У будь-якому випадку для України підтримання добросусідських взаємин 3 Польщею $\epsilon$ важливим. Тому чіткі сигнали офіційній Варшаві з боку офіційного Києва з приводу зацікавленості у практичному втіленні польсько-українського стратегічного партнерства були б важливими та далекоглядними.

Отже, цифровізація та розширення сфери IКТ наприкінці XX - поч. XXI ст. стали революцією у сфері дипломатії, оскільки вони кардинальним чином вплинули на розвиток сучасної дипломатичної практики, управління інформацією, публічної дипломатії, стратегічного планування, міжнародних переговорів та антикризового управління, набуваючи ознак т. зв. цифрової дипломатії, яка використовує ІКТ, інтернет та соціальні медіа для зміцнення дипломатичних відносин.

\section{References:}

1. 'Balczerovich: Zapad dolzhen udelyat' Ukraine gorazdo bol'she vnimaniya, chem Greczii' [Balcerowicz: The West should pay much more attention to Ukraine than to Greece]. (2015) Gordonua, [Online]. Available at: http://gordonua.com/news/worldnews/Balcerovich-Zapad-dolzhen-udelyatUkraine-gorazdo-bolshe-vnimaniya-chem-Grecii-94681.html.

2. Koziej, S. (2018). 'Co z tą nową zimną wojną' [What about this new cold war?]. Wszystko co najważniejsze, [Online]. Available at: https://wszystkoconajwazniejsze.pl/prof-stanislaw-koziej-co-z-ta-nowa-zimnawojna/.

3. 'Prezydent Andrzej Duda: do rozmów o Ukrainie mogliby dołączyć jej sąsiedzi i USA' [President Andrzej Duda: Ukraine's neighbors and the USA could join the talks about Ukraine]. (2015). Polskie Radio, [Online]. Available at: http://www.polskieradio.pl/5/3/Artykul/1492744,Prezydent-AndrzejDuda-do-rozmow-o-Ukrainie-mogliby-dolaczyc-jej-sasiedzi-i-USA. 
4. 'Prezydent Polshchi: Yevropa nebezpechno marhinalizuie viinu v Ukraini' [President of Poland: Europe dangerously marginalizes the war in Ukraine]. (2015). Yevroreiska pravda, [Online].

Available at: http://www.eurointegration.com.ua/news/2015/09/8/7037999/.

5. 'Pro «normanskyi format» slid zabuty - polskyi polityk' [The "Norman format" should be forgotten - a Polish politician]. (2015). Ukrinform, [Online]. Available at: http://www.ukrinform.ua/ukr/news/pro_normandskiy_format_slid_zabuti_polskiy_ politik_2093032.

6. Raubo, J. (2018). "Nowa zimna wojna" trwa czyli nie tylko o sprawie Skripala' [The "new cold war" continues, that is, not only about the Skripal case]. Infosecurity24, [Online]. Available at: https://www.infosecurity24.pl/nowa-zimnawojna-trwa-czyli-nie-tylko-o-sprawie-skripala.

7. 'Valensa: Konfliktovi na Skhodi Ukrainy mozhna bulo zapobihty' [Walesa: The conflict in eastern Ukraine could have been prevented]. (2015). Yevroreiska pravda, [Online]. Available at: http://www.eurointegration.com.ua/news/2015/02/19/7031063/.

(С)ітрофанова 0. О., 2021 


\section{Міжнародні відносини: теоретико-практичні аспекти \\ Випуск 7 (2021) \\ ISSN (print) 2616-745X; ISSN (online) 2616-7794}

\section{POLAND AND THE RUSSIAN-UKRAINIAN CONFLICT}

\section{Mitrofanova Oksana}

PhD in Political Science, Senior Research Fellow, State Institution "Institute of World History of NAS of Ukraine", Kyiv, Ukraine

ORCID: 0000-0002-2703-4919

kyivparis@ukr.net

The main objective of the study is to analyse the Poland's position towards the Russian-Ukrainian conflict, the annexation of Crimea and the regulation of the situation in Donbas. Concerning methodology the systematic method was used for studying of the Polish politicians' perception of the occupation of Donbas and annexation of Crimea and a comparative analysis was used for studying of the positions of European and Polish leaders towards the Poland's hypothetical participation in the Normandy format or other format for resolving the RussianUkrainian conflict. The Poland's official position on the Russian-Ukrainian conflict 2014-2020 has been analysed.

It has been proved that for Poland Ukraine is a zone of special interests. Official Warsaw seeks to play a significant role in resolving the Russian-Ukrainian conflict, because the failure of Ukraine will mean for Poland the deterioration of its own security situation. Currently, the Polish border with Ukraine is the EU's and NATO's border, so it would be optimal for Poland to move the borders of these organizations in the future to the East of Ukraine, so Poland strongly defends Ukraine's European and Euro-Atlantic ambitions.

It was concluded that Polish politicians have an understanding that turning the conflict in the Donbas into a frozen one will mean the presence of a permanent explosive situation. It is recommended that the clear signals to the official Warsaw from the official Kyiv about the interest in the practical implementation of the PolishUkrainian strategic partnership would be important and farsighted. It is highlighted that the implementation of Polish strategy on the Russian-Ukrainian conflict depends on the strategies of the main players of the European strategic space. The Polish position is perceived as pro-American by French and German authorities, so the official Paris and Bonn avoid involving Poland in the negotiations on the situation in the Donbas. However, Poland alone is not capable of influencing the regulation of the Russian-Ukrainian conflict, Warsaw must act together with the most powerful players.

Key words: Ukraine; Poland; Normandy format; Crimea; Donbas. 


\title{
ПОЛЬША И РОССИЙСКО-УКРАИНСКИЙ КОНФЛИКТ
}

\author{
Митрофанова Оксана Александровна \\ кандидат политических наук, старший научный сотрудник, \\ ГУ «Институт всемирной истории НАН Украины», \\ 2. Киев, Украина \\ ORCID: 0000-0002-2703-4919 \\ kyivparis@ukr.net
}

Целью является анализ позиции Польши относительно российскоукраинского конфликта, аннексии Крыма и урегулирования ситуации на Донбассе. Среди методов были использованы системный для изучения восприятия польскими политиками оккупации Донбасса и аннексии Крыма и компаративный анализ позиций европейских и польских деятелей относительно гипотетического участия Польши в нормандском или другом формате по урегулированию российско-украинского конфликта. Проанализирована официальная позиция Польши относительно российскоукраинского конфликта 2014-2020 гг.

Доказано, что для Польши Украина является зоной особых интересов. Официальная Варшава стремится играть значительную роль в урегулировании российско-украинского конфликта, потому что провал Украины будет означать для Польши ухудшение собственной ситуации в сфере безопасности. Сейчас польская граница с Украиной является границей ЕС и НАТО, поэтому оптимальным для Польши было бы перемещение границ этих организаций в будущем на восток Украины, поэтому Польша настойчиво отстаивает евроинтеграционные и евроатлантические амбиции Украины.

Сделан вывод, что у польских политиков есть понимание, что преобразование конфликта на Донбассе на замороженный будет означать наличие постоянной взрывоопасной ситуации. Сделаны рекомендации, что четкие сигналы официальной Варшаве со стороны официального Киева по поводу заинтересованности в практическом воплощении польско-украинского стратегического партнерства были бы важными и дальновидными. Выделено, что реализация польской политики в отношении российско-украинского конфликта зависит от стратегий основных игроков европейского стратегического пространства.

Польская политика воспринимается как проамериканская французскими и немецкими властями, поэтому официальный Париж и Бонн избегают привлечения Польши к переговорам по ситуации на Донбассе.

(C)Мітрофанова 0. 0., 2021 
Міжнародні відносини: теоретико-практичні аспекти

Випуск 7 (2021)

ISSN (print) 2616-745X; ISSN (online) 2616-7794

Впрочем, самостоятельно Польша не является способной влиять на урегулирование российско-украинского конфликта, Варшава должна действовать совместно с мощными игроками.

Ключевые слова: Украина; Польша; нормандский формат; Крым; Донбасс. 